
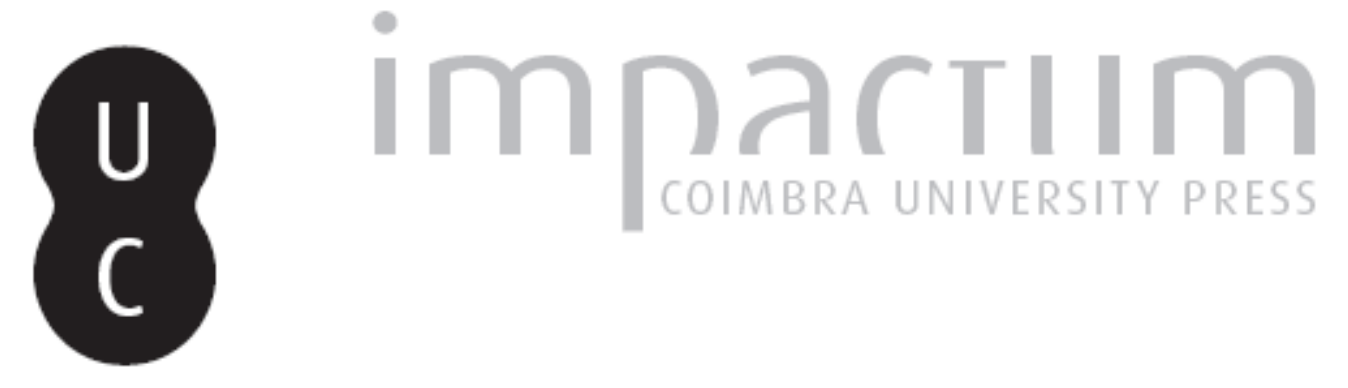

\title{
Utopia e profetismo no Século das Luzes: D. José (1761-1788), Príncipe do Brasil, Imperador do Mundo
}

\author{
Autor(es): $\quad$ Buescu, Ana Isabel \\ Publicado por: Centro de História da Sociedade e da Cultura \\ URL \\ persistente: \\ URI:http://hdl.handle.net/10316.2/39395 \\ DOI: \\ DOI:http://dx.doi.org/10.14195/1645-2259_13_13
}

Accessed : $\quad$ 26-Apr-2023 15:21:46

A navegação consulta e descarregamento dos títulos inseridos nas Bibliotecas Digitais UC Digitalis, UC Pombalina e UC Impactum, pressupõem a aceitação plena e sem reservas dos Termos e Condições de Uso destas Bibliotecas Digitais, disponíveis em https://digitalis.uc.pt/pt-pt/termos.

Conforme exposto nos referidos Termos e Condições de Uso, o descarregamento de títulos de acesso restrito requer uma licença válida de autorização devendo o utilizador aceder ao(s) documento(s) a partir de um endereço de IP da instituição detentora da supramencionada licença.

Ao utilizador é apenas permitido o descarregamento para uso pessoal, pelo que o emprego do(s) título(s) descarregado(s) para outro fim, designadamente comercial, carece de autorização do respetivo autor ou editor da obra.

Na medida em que todas as obras da UC Digitalis se encontram protegidas pelo Código do Direito de Autor e Direitos Conexos e demais legislação aplicável, toda a cópia, parcial ou total, deste documento, nos casos em que é legalmente admitida, deverá conter ou fazer-se acompanhar por este aviso.

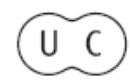



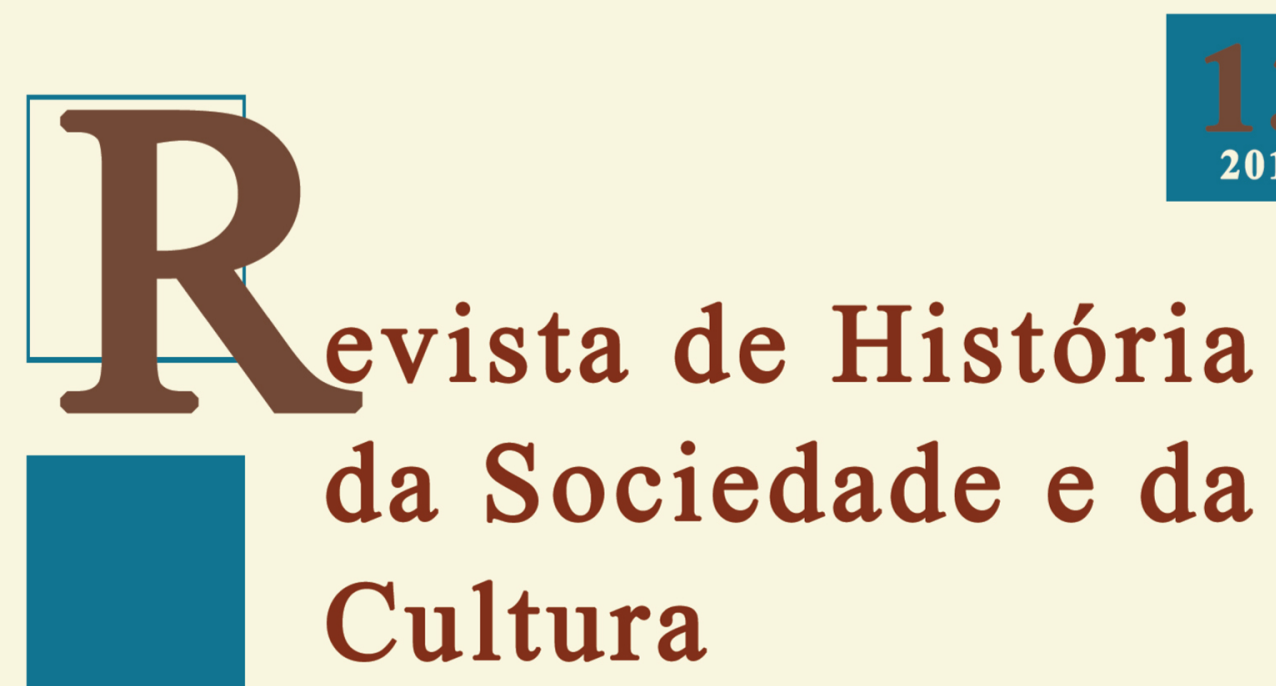

2013

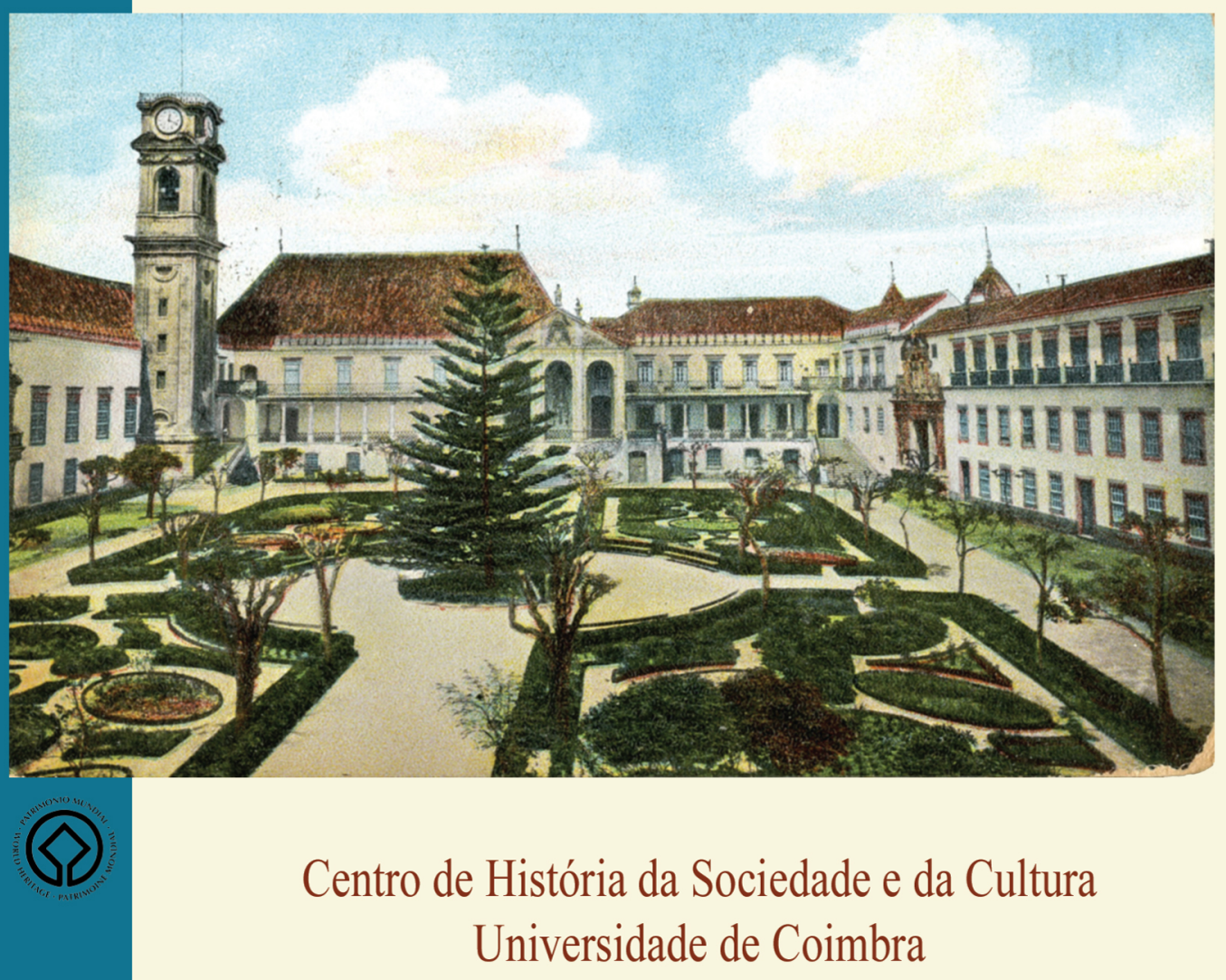

Coimbra 


\title{
Utopia e Profetismo no Século das Luzes D. José (1761-1788), Príncipe do Brasil, Imperador do Mundo*
}

\author{
Ana Isabel Buescu \\ Faculdade de Ciências Sociais e Humanas da UNL/ CHAM \\ anabuescu@netcabo.pt \\ Texto recebido em /Text submitted on: 22/02/2013 \\ Texto aprovado em /Text approved on: 31/07/2013
}

\section{Resumo/Abstract:}

Tendo por base um manuscrito da Biblioteca da Ajuda, oferecido a D. José, Príncipe do Brasil, este texto procura evidenciar como a "constelação mítica" das origens de Portugal e do seu destino imperial, em que o milagre de Ourique e o Juramento de Afonso Henriques têm um lugar central, estão ainda presentes na cultura política no século das Luzes. Em gestação desde pelo menos o século XV, tal construção ideológica culminaria no século XVII na utopia, messiânica e profética, do Quinto Império. Caberia à nação portuguesa, escolhida por Deus nos campos de Ourique para espalhar universalmente a fé, erguer um império cristão onde a paz e a concórdia reinariam. Dedicada a um príncipe então destinado a ser rei de Portugal não é, portanto, uma concepção insólita ou excepcional: antes continua a veicular, no "racional" século XVIII, uma memória nacional ancorada no mito fundador. Mais: como veremos, o século XVIII ajudou activamente a transmitir o edifício mítico das origens ao século XIX, até à polémica em que pontificou Alexandre Herculano.

This essay is based on a late seventeenth manuscript, the Fidelidade Portuguesa, which can be found at the Biblioteca da Ajuda. It was intended to be offered to the then heir to the Portuguese throne, Prince José. The main objective of this text it to stress how the "mythical constellation" of the origins of the Portuguese monarchy (the miraculous "appearance" of Christ to the first king at the battlefield against the Moors and the "Oath" of Afonso Henriques) and its future imperial destiny as the Christian Fifth Empire are still central in the political and historical discourse in the Enlightenment. Based upon some medieval legends, the "miracle" of the appearance of Christ evolved and became, during the sixteenth century, fully integrated in the political discourse of the Portuguese Crown. Finally, in the context of the loss of independence to Spain in 1580, this mythical discourse became a messianic believe, where the future Christian Fifth Empire with spiritual and temporal power, set to take its place in a new era, would become a reality with the Portuguese monarchy. Dedicated to the prince who would (but didn't) become king, we can conclude that this ideological perspective is not exceptional, but the vehicle of a persistent ideological believe in the rational eighteenth century. And more: it was, decisively, the eighteenth century, as this manuscript abundantly shows, that transmitted this myth of origins to the nineteenth century, when it was the object of the debate in which the great Portuguese historian Alexandre Herculano actively participated.

Palavras chave/Keywords:

Príncipe D. José; Ourique; Quinto-Império; Século das Luzes.

Prince D. José; Ourique; Fifth Empire; Enlightenment.

* Texto inédito, reformulado, da comunicação apresentada ao Colóquio A Imagética de uma Nova Humanidade - representações identitárias no tempo e no espaço (FLUL, 2009). 
Ao P. João Francisco Marques

"Será de Portugal o Imperio do Mundo, e ao seu Solio tributarão os mayores Monarcas, e Lisboa será coroada cabeça do Universo"

\section{Um códice setecentista da Biblioteca da Ajuda - autoria e destinatário}

Nos fundos da Biblioteca da Ajuda, que incorpora muito daquilo que foi a antiga biblioteca dos reis de Portugal, o título de um códice do século XVIII chamou a nossa atenção: Fidelidade Portugueza às vozes de Jesus Christo. Misterioza Sucesão de seos Monarcas, dezempenhada no Senhor D. Joze Francisco Xavier de Paula Antonio Domingos Agostinho Anastacio, Principe do Brazil, Futuro Imperador Maximo ${ }^{2}$. Trata-se de um volume in folio de 260 folhas, encadernado, com um número muito apreciável de ilustrações aguareladas, em bom estado de conservação e envolto numa já puída capa de seda rosa. $O$ códice não ostenta qualquer data.

O seu destinatário era o príncipe D. José (1761-1788), filho primogénito da rainha D. Maria I e de D. Pedro III, e neto do rei D. José, figura hoje pouco conhecida, mas que, pela sua condição de filho varão mais velho, estava destinado a ser rei. O seu título de Príncipe do Brasil remetia, aliás, para a sua condição de herdeiro do trono, pois fora "[...] estabelecido pelo Senhor Rey D. João $4^{\circ}$ para os primogénitos dos reaes successores da Coroa Luzitana". Nascido em 1761 na "Real Barraca" da Ajuda, o príncipe D. José recebeu o nome do avô materno e uma cuidada educação, determinada pelo seu régio avô mas traçada pela mão de $\mathrm{Pombal}^{4}$ em que

1 Fidelidade Portugueza..., fol. 207. V. nota seguinte.

2 Biblioteca da Ajuda (Lisboa), 49-XI-17.

3 BA, 49-XI-17, fol. 198. Título criado por D. João IV em 1645, a favor de seu filho primogénito, D. Teodósio. O príncipe D. José foi também príncipe da Beira $\left(2^{\circ}\right)$, título criado em 1734 por D. João V a favor da futura D. Maria I.

4 Biblioteca Pública de Évora, cod. 592-14, "Decreto sobre a educação e instrucção do Príncipe D. José" (cópia). Maria Beatriz Nizza da Silva estuda uma outra cópia deste decreto do rei D. José I, de 7 de Dezembro de 1768, sobre a educação a ministrar ao seu neto, presuntivo futuro herdeiro da coroa portuguesa, em A educação de um príncipe no período 
pontificaram o matemático Miguel Franzini ${ }^{5}$ e o prestigiado homem da Igreja e de letras, Frei Manuel do Cenáculo Villas-Boas, também seu confessor, um dos expoentes da cultura das Luzes em Portugal ${ }^{6}$.

A educação recebida parece ter dado frutos, sendo D. José considerado, em vida, um homem dado às coisas do mundo da cultura, atento à política $\mathrm{e}$ às ideias, prometendo tornar-se um rei esclarecido. A moderna historiografia, que pouco tem olhado para esta figura, recolheu e tendeu a confirmar a imagem legada do príncipe do Brasil -, o único estudo sobre o príncipe, publicado em 1989 por ocasião do segundo centenário da sua morte, intitula-se Um príncipe iluminado português: D. José (1761-1788)7. Casado com a sua tia materna, a infanta D. Maria Francisca Benedita em 1777, poucos dias antes da morte do rei D. José, casamento do qual não houve filhos, o príncipe do Brasil veio a falecer, de varíola, aos 28 anos de idade, a 11 de Setembro de 1788, em Lisboa. Com a sua morte, foi o seu irmão, o infante D. João (n. 1767), quem herdou o título de príncipe do Brasil e veio a ser rei de Portugal. Morrendo prematuramente e não cumprindo, afinal, o seu régio destino, a figura de D. José, sobre cujos ombros pendiam grandes expectativas $^{8}$ e cuja morte foi muito chorada ${ }^{9}$, viu-se progressivamente envolta em obscuridade, caindo praticamente no esquecimento.

pombalino. Revista de História das Ideias, vol. IV, O Marquês de Pombal e o seu Tempo, tomo I (1982-83) 377-383.

5 Também mestre de matemática do filho de Pombal, D. José Francisco.

6 Sobre Cenáculo, v., entre vários outros estudos, os de MARCADÉ, Jacques - Frei Manuel do Cenáculo Villas Boas. Évêque de Beja, Archevêque d'Évora /1770-1814). Paris: Centro Cultural Português, 1978; VAZ, Francisco A. Lourenço e CALIXTO, José António Frei Manuel do Cenáculo construtor de bibliotecas. Casal de Cambra: Caleidoscópio, 2006.

7 FERRO, João Pedro - Um príncipe iluminado português: D. José (1761-1788). Lisboa: Lucifer Edições, 1989.

8 Num quadro de incerteza política, em que se destaca o processo que conduz à queda de Pombal e consequente viragem política (a "Viradeira") e a fragilidade psíquica da rainha D. Maria, sua mãe. V. RAMOS, Luís de Oliveira - D. Maria I. Lisboa: Círculo de Leitores, 2007; BOLÉO, Luísa de Paiva - D. Maria I. A rainha Louca. Lisboa: A Esfera dos Livros, 2009.

9 V. a abundante lista de publicações e elogios fúnebres editados aquando do seu passamento, em No $2^{\circ}$ Centenário da Morte do Príncipe D. José (1761-1788). Exposição organizada pela Sociedade Portuguesa de Estudos do Século XVIII, em colaboração com o Palácio de Queluz e o Grémio Rebeldia, Palácio de Queluz, Dez ${ }^{\circ} 1988-$ Fev $^{\circ}$ de 1989. Lisboa, 1988, 82-95. 
É, pois, a este príncipe que é dirigida a Fidelidade Portugueza... ${ }^{10}$, longo e cuidado manuscrito de 260 fólios, que não apresenta indicação explícita de autoria nem data. Sem podermos atribuir-lhe uma data exacta, é possível situá-la entre 1777, ano da subida ao trono de D. Maria I, que figura no manuscrito na sua condição de rainha de Portugal - e 1788, ano da morte do príncipe do Brasil, a quem a obra é dirigida. Quanto à autoria, não constando embora no texto, ela é comprovada num outro documento existente na mesma Biblioteca, que ajuda ainda a esclarecer de que forma o manuscrito foi incorporado na biblioteca régia portuguesa ${ }^{11}$.

A 5 de Fevereiro de 1836 um certo Manuel António da Costa de Lima endereçava uma carta à rainha $\mathrm{D}$. Maria II, que se iniciava nestes termos:

\section{"Senhora}

Hum benemerito Parente meu, o Beneficiado Nicolao Joze Barbosa, natural da Villa de Vianna do Minho, dotado de varias habilidades nas Artes Liberaes, tendo composto curiozamente varias Obras scientificas, que levarão descaminho, deixoume em Legado, entre outros, este preciozo e singular Livro original, intitulado = Fidelidade Portugueza, o qual elle intentava dedicar ao Excelso e Grande Príncipe o Senhor D. José Segundo, de Saudoza Memoria, Augusto Tio de Vossa Magestade Fidelíssima"12.

O destaque com que o manuscrito da Fidelidade Portugueza, um legado que lhe ficara do seu falecido parente, surgia na carta de Manuel da Costa de Lima, fazendo dele oferta à rainha, é justificado pela finalidade da

${ }^{10}$ Numa miscelânea da BNP de opúsculos de início do seculo XIX, o no 3 intitula-se Origem da Fidelidade Portugueza, Lisboa: Impressão Régia, 1811, que consultámos em virtude da proximidade com o título do manuscrito da Biblioteca da Ajuda. Claramente inserido, em termos de conteúdos, no contexto das invasões francesas e da fuga da família real e corte para o Brasil, é um pequeno texto de cariz histórico-patriótico, que faz um resumo da História portuguesa, desde os Lusitanos ao século XIX, procurando demonstrar a constante e ininterrupta fidelidade dos Lusitanos/Portugueses à sua história e aos seus reis desde a fundação até ao culminante momento da fuga para o Brasil. Na referência a Afonso Henriques, não consta a referência à dimensão miraculosa de Ourique, nem qualquer alusão a uma histórica tocada pelo sagrado, pelo que, salvo a coincidência do título e o tom vibrante, este opúsculo pouco tem a ver com a estrutura e sentido ideológico central da Fidelidade Portugueza... da BA.

${ }^{11}$ BA, 54-X-32, no 490. Agradecemos à Dr ${ }^{\mathrm{a}}$ Conceição Geada, da Biblioteca da Ajuda, a chamada de atenção para este importante documento com referência à autoria da Fidelidade Portugueza.

${ }^{12} \mathrm{BA}, 54-\mathrm{X}-32, \mathrm{n}^{\circ} 490$, fol. 1-1v. 
missiva: apresentando-se perante a monarca como alguém que já servira "Vossa Magestade e ao Estado", durante cerca de doze anos, na carreira da magistratura ${ }^{13}$, Manuel da Costa de Lima tivera de abandonar, por "negocios domesticos", como dizia, a carreira que abraçara. Agora, achando-se "ainda em vigor, e mais dezembaraçado para continuar na sobredicta honorifica Carreira", oferecia-se para novamente se colocar ao "Serviço de Vossa Magestade, e da Nação, a quem dezejo ser util no Emprego, que de mim se confiar" ${ }^{14}$.

A forma de "solenizar", por assim dizer, o pedido que fazia à rainha era ofertar-lhe o "preciozo, e singular Livro original", da autoria do seu familiar Nicolau José Barbosa, que lho havia deixado; não um livro qualquer, mas um livro único, como só um manuscrito podia ser, um livro materialmente rico na profusão dos seus desenhos e na cor das suas ilustrações mas, acima de tudo, do nosso ponto de vista, um livro com uma indiscutível ligação simbólica com a monarquia e a sua memória, que o tornava um objecto absolutamente adequado e próprio para oferecer à rainha de Portugal. Tal facto não terá passado despercebido a Manuel da Costa de Lima. E o livro entrou na biblioteca da rainha.

Esta carta de 1836 permite, pois, desvendar a questão da autoria da Fidelidade Portugueza, mas apenas isso. Na verdade, pouco mais conseguimos apurar sobre o beneficiado Nicolau José Barbosa, natural de Viana do Minho, já que o seu nome não figura em qualquer dicionário ou biblioteca de autores, o que nos impede de perceber a sua inserção social e trajectória profissional e, até, a proximidade com a corte a cujo príncipe herdeiro tinha expressa intenção de dedicar a Fidelidade Portugueza, talvez mesmo oferecer. Esta não é, aliás, uma questão de somenos, já que uma obra com estas características não se destinava à fruição do seu autor, ou a ser apenas a eventual matriz de uma futura edição impressa: ao realizá-la, Nicolau José Barbosa acalentava certamente expectativas que não temos elementos para definir nem situar. Apenas sabemos, novamente pela carta do seu familiar que, além desta, foi Nicolau Barbosa autor de outras

13 “ [...] já na qualidade de Juiz de fóra de Ourém, já de Auditor em Thomar, e já de Corregedor, Provedor, Superintendente da Candelaria e Conservador de Fabricas de Seda em Bragança [...]". Ibidem, fol. 2.

${ }^{14}$ Ibidem, fol. 2-2v. 
"Obras scientificas, que levarão descaminho". Existiu um Nicolau José Soares Barbosa (1750-1833), bacharel, professor da língua grega da Vila de Tomar, de gramática no Colégio das Artes e lente na cadeira de Retórica e Poética na Universidade de Coimbra, falecendo, com 83 anos, na sua quinta e Monte Arroio em Coimbra, que pensámos poder corresponder ao autor da Fidelidade Portugueza.... Dos seus vários irmãos destacaram-se Luís Soares Barbosa, médico em Leiria, o padre António Soares Barbosa, professor na Universidade de Coimbra, e o padre Jerónimo Soares Barbosa (1737-1816), sócio da Academia das Ciências, professor de Humanidades e deputado da Junta Literária na Universidade. Mas a naturalidade da família é Leiria, e a carta do parente do autor da Fidelidade... refere explicitamente que Nicolau José Barbosa era natural de Viana do Minho [Castelo], pelo que descartamos esta hipótese de identificação. Há contudo informações sobre a nossa figura no Arquivo Distrital de Braga, a justificar uma ulterior pesquisa $^{15}$. Por outro lado, esse aprofundamento na investigação torna-se ainda mais pertinente dado existir, segundo nos foi comunicado, alguns manuscritos depositados no Arquivo Distrital de Braga que reproduzem um programa iconográfico idêntico ao do códice da Ajuda, o que parece sugerir uma possível proximidade ou, até, sobreposição de autoria com o códice da Ajuda ${ }^{16}$.

${ }^{15}$ Informações recolhidas em http://www.familiasdeleiria.com/pd1.htm, consultado em 10 de Fevereiro de 2013. Também no Diccionario Bibliographico Portuguez de SILVA, Inocêncio Francisco da Silva não encontrámos, consultados vários dos seus volumes, qualquer referência ao autor da Fidelidade Portugueza. No cartório da Câmara Eclesiástica de Braga / fundo Inquirições De Generel - Arquivo Distrital de Braga, o processo no 13719, pasta 584, relativo à habilitação de Nicolau José Barbosa, realizada em 1751.03.22, esclarece que aquele beneficiado, filho de João Barbosa Tavares e Micaela Arcangela Pereira, era natural da freguesia de Viana do Castelo - Santa Maria Maior. http://epl.di.uminho.pt/ jcr/PROJS/ inquiricoes/novo pgsql/igenere/fs alfabetica.html.

${ }^{16}$ De acordo com esta informação, muitas das imagens são iguais (Cf. figura 4 Cronologia dos Senhores Reis de Portugal; figura 5 - Fidelidade Portugueza; figura 9 - Alusão ao Imperio Maximo do Serenissimo Principe do Brazil, etc.). Ms 355 Portugal Glorioso (209 fls); Ms 355 A Gloria de Portugal; Cronologia dos Reis de Portugal (fls 6 a 36); Ms. 355C Mas quem será o Imperador Máximo? (fls. 179-203). 


\section{A História do reino de Portugal: uma visão profética e messiânica}

O "preciozo, e singular Livro" oferecido à rainha D. Maria II em 1836 é um livro sobre história de Portugal. Mas logo o título adverte para que se trata de uma certa visão dessa mesma história: a "Misterioza Sucesão" dos monarcas portugueses, desde o Conde D. Henrique, "Gloriozo Progenitor da Monarchia Luzitana ${ }^{17}$, até D. Maria I e D. Pedro III, $23^{\circ}$ s reis de Portugal ${ }^{18}$, são concebidos como momentos e etapas que preparam a consumação de um império católico e universal, erguido sob o signo da monarquia portuguesa e protagonizado pelo futuro monarca, o jovem príncipe do Brasil. Assim, a figura do príncipe D. José, que culmina a evocação da galeria de todos os reis de Portugal, não representa apenas uma natural e legítima sucessão na coroa portuguesa, mas é inscrita num horizonte mais amplo, promissório e imperial, à escala do mundo. Na verdade, o futuro D. José II, príncipe do Brasil, perfila-se, de acordo com esta visão, como o "Futuro Imperador Máximo"19, que reinará sobre todo o orbe: "Será de Portugal o Imperio do Mundo, e ao seu Solio tributarão os mayores Monarcas, e Lisboa será coroada cabeça do universo"20.

\subsection{A constelação mítico-política de Ourique (séculos XV-XIX)}

A ideia central da Fidelidade Portugueza filia-se, de forma indiscutível, na "constelação mítico-política" relativa à monarquia portuguesa que, em gestação desde o século $\mathrm{XV}^{21}$, cristalizada no século XVI em torno do episódio fundador e sacralizador de Ourique, culminaria no século XVII, antes da Restauração de 1640 e depois dela, como demonstram os trabalhos de João Francisco Marques, na utopia, messiânica e profética, do Quinto

${ }^{17}$ BA, 49-XI-17, fols. 10-22.

${ }^{18}$ Ibidem, fols. $187-197 \mathrm{v}$.

${ }^{19}$ Ibidem, fol. 198.

${ }^{20}$ Ibidem, fol. 207.

${ }^{21}$ CINTRA, Luís Filipe Lindley - Sobre a formação e evolução da lenda de Ourique (até à Crónica de 1419). Revista da Faculdade de Letras de Lisboa, tomo XXIII, $3^{\mathrm{a}}$ série, 1 (1957) 168-215; NASCIMENTO, Aires Augusto - O milagre de Ourique num texto latino-medieval de 1416. Revista da Faculdade de Letras de Lisboa, 4ª série, 2 (1978) 365-374. 
Império $^{22}$. Segundo esta, caberia à Nação Portuguesa, escolhida por Deus nos campos de Ourique para espalhar universalmente a fé cristã, como testemunhara Afonso Henriques no seu "Juramento", erguer um império cristão onde para sempre a paz e a concórdia reinariam. Depois dos outros quatro grandes impérios que o mundo conhecera, o Quinto Império, cristão e beatífico, seria português. Não nos vamos deter com pormenor na edificação desta "constelação mítica" já por nós estudada ${ }^{23}$, imprescindível para compreender de que forma ela constituiu um corpo ideológico coerente e sedimentado enquanto representação das origens da nacionalidade e visão promissória de um futuro colectivo a cumprir.

O que pretendemos sublinhar é que o aparelho lendário de Ourique milagre, batalha, vitória, fundação da nacionalidade - tal como surge numa obra como a Fidelidade Portugueza, dedicada a um príncipe destinado então a ser rei de Portugal, não é, portanto, uma concepção insólita ou excepcional: antes continua a veicular, no "racional" século XVIII, uma memória nacional indiscutivelmente ancorada no mito fundador das origens, "monumento" - chave de uma interpretação secular do Portugal independente, e no

${ }^{22}$ MARQUES, João Francisco - A Parenética Portuguesa e a Dominação Filipina, 2 vols.. Porto: INIC, 1986; IDEM - A Parenética Portuguesa e a Restauração 1640-1668. A Revolta e a Mentalidade, Prefácio de Jean Delumeau, 2 vols.. Porto: INIC, 1989; IDEM A Utopia do Quinto Império e os Pregadores da Restauração, Organização, Introdução e Notas de João Francisco Marques. Vila Nova de Famalicão: Edições Quasi, 2007; v. ainda BUESCU, Ana Isabel - 'Sentimento' e 'Esperanças' de Portugal - da legitimidade de D. João IV. Penélope. Fazer e Desfazer a História, 9/10, Actas do Encontro sobre A Restauração e a sua Época (1993) 169-188. Sobre o enraizamento da ideia do Quinto Império na sua articulação ideológica com o espírito de Cruzada, v. THOMAZ, Luís Filipe Reis e ALVES, Jorge Santos - Da Cruzada ao Quinto Império, in BETHENCOURT, Francisco e CURTO, Diogo Ramada (ed.) - A Memória da Nação, Colóquio do Gabinete de Estudos de Simbologia (1987), Lisboa: Sá da Costa, 1991, p. 81-165.

${ }^{23}$ Expressão de GODINHO, Vitorino Magalhães. BUESCU, Ana Isabel Buescu Um mito das origens da nacionalidade: o milagre de Ourique, in A Memória da Nação, cit., p. 49-69; IDEM - Vínculos da memória: Ourique e a fundação do reino in CENTENO, Yvette K. (ed.) - Portugal: Mitos Revisitados. Da Fundação à Modernidade. Lisboa: Edições Salamandra, 1993, p. 11-50; IDEM - A profecia que nos deu patria: o milagre de Ourique na cultura portuguesa (séculos XV-XVIII). Actas do $2^{\circ}$ Congresso Histórico de Guimarães. D. Afonso Henriques e a sua Época (Guimarães, Outubro de 1996), vol. 3, D. Afonso Henriques na História e na Arte. Guimarães: Câmara Municipal e Universidade do Minho, 1997, p. 195-211. IDEM - Afonso Henriques no século XVI: momentos \& imagens, corpos \& lugares. Na corte dos reis de Portugal. Saberes, ritos e memórias. Lisboa: Colibri, 2010, p. 185-209. 
destino promissório e imperial do reino. Mais: como veremos, o próprio século XVIII ajudou activamente a transmitir o edifício mítico das origens de Portugal ao século XIX, até à definitiva polémica em que pontificou Alexandre Herculano ${ }^{24}$.

A configuração do duplo episódio - militar e sobrenatural - como momento da fundação e a sua incorporação na memória "oficial" do reino encontrou um outro desenvolvimento também ele significativo no extremo final do reinado de D. João III (1521-1557) quando, em 1556, se deu início à primeira tentativa de canonização de Afonso Henriques, processo que tem de entender-se no duplo quadro da piedade e do zelo dos cónegos de Santa Cruz de Coimbra e de uma atenção de que era objecto a nível oficial. Já D. Manuel (1495-1521) procurara dignificar a memória do fundador da monarquia, mandando edificar-lhe novo e magnífico túmulo em Santa Cruz de Coimbra $^{25}$, em cujo epitáfio passava a constar a referência à aparição ${ }^{26}$. De ambas as iniciativas régias resulta clara a importância ideológica que no século XVI a monarquia conferia à comemoração das origens,

${ }^{24}$ BUESCU, Ana Isabel - O Milagre de Ourique e a História de Portugal de Alexandre Herculano. Uma Polémica Oitocentista. Lisboa: INIC, 1987; IDEM - Ourique no século XIX: polémica e perplexidade, in A Construção Social do Passado, Actas do Encontro realizado a 27 e 28 de Novembro de 1987. Lisboa: APH, 1992, p. 191-204. Se a polémica oitocentista em torno do milagre de Ourique cedo se revestirá de contornos marcadamente ideológicos no âmbito do confronto político de então, o seu ponto de partida incontestável - e que até ao fim não deixará de integrá-la - é a questão da tradição fundadora e, por parte dos seus defensores, a necessidade de a conservar, independentemente da historicidade do facto, contra a crítica "dissolvente" de Herculano. A maior perplexidade reside na impossibilidade em circunscrever esta polémica à hipocrisia e à feição reaccionária com que Herculano julgava caracterizá-la em bloco. A polémica oitocentista de Ourique não é apenas a questão do clero; ela vem também demonstrar que em meados do século XIX a tradição fundadora correspondia a uma representação multissecular das origens, sem dúvida fortemente ideologizada e apropriada por círculos políticos bem determinados, mas ainda operatória.

${ }^{25}$ GÓIS, Damião de - Crónica do Felicissimo Rei D. Manuel (1566-67), IV Parte, cap. LXXV (edição de J. M. Teixeira de Carvalho e David Lopes). Coimbra: Imprensa da Universidade, 1926, 204. A estátua jacente do novo túmulo de Afonso Henriques, na capela-mor da igreja do Mosteiro de Santa Cruz, foi muito provavelmente obra do escultor francês Nicolau Chanterene, que deixou também o seu nome ligado ao Mosteiro dos Jerónimos. V. DIAS, Pedro - Nicolau Chanterene, escultor da Renascença. Lisboa: Publicações Ciência e Vida, 1987, p. 63.

${ }^{26}$ BRANDÃO, Frei António - Monarchia Lusitana, III Parte, Livro VI, cap. XXXVIII, fols. 266v-267v. V. também CASTRO, Augusto Mendes Simões de - Os tumulos de D. Affonso Henriques e de D. Sancho I. Coimbra, Imprensa da Universidade, 1885. 
bem como o lugar central que Ourique tinha nessa celebração. A representação iconográfica do milagre na magnífica genealogia iluminada encomendada pelo infante D. Fernando (1507-1534), irmão de D. João III, confirma não só a sua definitiva inscrição na memória das origens do reino, como dá conta do relevo que esse processo e essa representação tinham nos círculos da corte régia no século de Quinhentos ${ }^{27}$.

Amultiplicidade dos planos nos quais é possível detectar a funcionalidade do episódio de Ourique permite concluir que ele se encontrava indiscutivelmente apropriado pelo discurso ideológico no século XVI, e incorporado numa memória "nacional" do reino impulsionada e sancionada pela coroa. Mas seria o século XVII, por um conjunto de factores e contextos, em particular o da situação política marcada pela monarquia dual, a assinalar a sua definitiva consagração, facto estreitamente ligado ao labor da historiografia alcobacense, e tomou forma com a "descoberta" do juramento de Afonso Henriques em Alcobaça, publicado pela primeira vez na segunda edição dos Diálogos de Vária História (1599) de Pedro de Mariz, e que reapareceu, pela mão de Frei Bernardo de Brito, na Crónica de Cister (1602). Além da sua reprodução frequente, em latim ou português, em muitas obras impressas, o juramento seria objecto de intensa circulação manuscrita, quer em miscelâneas de carácter histórico e literário ${ }^{28}$, de cariz sebastianista ${ }^{29}$, ou ainda em obras que se ocupam da descrição das armas nacionais e da nobreza do reino ${ }^{30}$. A "descoberta" do juramento conferia, como é fácil

${ }^{27}$ AGUIAR, António - A genealogia iluminada do infante D. Fernando por António de Holanda e Simão Bening. Estudo histórico e crítico. Lisboa: s.e., 1962, reprodução do fol. 8,32 .

${ }^{28} \mathrm{~V}$. apenas a título de exemplo, BNP, cod. 560, fols. 77-78; cod. 665, fols. 258-259; cod. 8572, fols. 25-25v; Pomb. 68, fols. 14-17; IAN/TT, misc. ms. 1113, fol. 155; misc. ms. 1817, fol. 142; BGUC, cod. 169, fols. 89v-91v; cod. 180, fols. 132-134; cod. 348, fols. $43 \mathrm{v}-45$; cod. 488 , fols. $10-12$; cod. 493 , fols. $193 \mathrm{v}-194 \mathrm{v}$; cod. 510 , fols. $254-254 \mathrm{v}$; cod. 581, fols. 212v-215; BA, 49-XI-46, fols. 9-13 e fols. 291-297v, esta cópia antecedida das "actas das Cortes de Lamego", fols. 279-289, 50-V-35, fols. 66v-68;51-I-66, 2-3;

${ }^{29} \mathrm{BNP}$, cod. 125 , fols. $74-77 \mathrm{v}$; cod. 400 , fols. $198 \mathrm{v}-201 \mathrm{v}$; cod. 551 , fols. $70-74$; cod. 10740, p. 278-283.

${ }^{30}$ V. por exemplo, BGUC, cod. 490, fols. 269v-280v. A descrição da origem das armas nacionais, dadas por Cristo em Ourique a Afonso Henriques funciona aqui como uma "introdução" a um "Compendio breue na materia de nobresa e fidalguia destes Reynos (fols. 272-280v), que encerra com a descrição das armas de algumas cidades e reinos. V. ainda BNP, cod. 655, Manifesto politico do fundamento e origem das Armas dos Reynos 
entender, uma nova dimensão ao episódio, e representava o completar da tradição: se a batalha e o milagre eram os elementos de fundação, o "juramento" de Afonso Henriques, do qual constavam as promessas de Cristo ao primeiro monarca, representava a garantia da continuidade em que avultava uma inequívoca dimensão promissória e imperial ${ }^{31}$.

Nesta noção de que o milagre representava também um chamamento do "novo povo eleito", o princípio justificativo da missão universal dos portugueses, se estabelecia, aliás, a estreita articulação entre o mito fundador e o messianismo sebástico, um dos tópicos que assinala e constitui uma das singularidades da cultura portuguesa, com uma expressão muito particular nos finais do século XVI e no século XVII ${ }^{32}$. O P. António Vieira, figura que de forma mais expressiva dá corpo a essa confluência, inscrevia de modo decisivo a fundação do reino e a aparição de Cristo, primeiro e último garante do Quinto Império, no quadro do seu pensamento milenarista e messiânico ${ }^{33}$. Vieira via nas palavras de Cristo - "Volo in te et in semine tuo, imperium mihi stabilire" - a promessa de um império cristão universal, encarnado por um descendente do primeiro rei português. Destino e vocação imperiais, realidade a cumprir, implícita nas palavras de Cristo ao fundador do reino. Toda esta concepção ideológica não só está presente na Fidelidade Portugueza de Nicolau José Barbosa, como é ela que representa, sem dúvida, o seu fio condutor.

A sua consagração definitiva seria indissociável da Restauração, que nele encontrou, a par da recuperação das cortes de Lamego, um referente indispensável ao seu discurso legitimador. É esse o sentido do episódio,

de Portugal..., fols. 178v-187v. Paradigma desta "matriz" de Ourique como origem das armas encontramo-lo nos belíssimos Tropheus Lusitanos (1632) de António Soares de Albergaria, em que a figuração heráldica dos escudos e armas dos titulares da nobreza do reino de Portugal é antecedida de uma gravura do "Apparecimento de Christo a El Rey Dom Affonso Henriques" (fol. 7), a que se seguem as "Armas do Reyno de Portugal, dadas a ElRey Dom Affonso Henriques".

${ }^{31}$ BRANDÃO, Frei António - Monarchia Lusitana, III Parte, Livro X, cap. V, fols. $128 \mathrm{v}-129$.

${ }^{32}$ Sobre a articulação entre as figuras de Afonso Henriques e D. Sebastião e o messianismo político, v. VALENSI, Lucette - Fábulas da Memória. A Gloriosa Batalha dos Três Reis, Lisboa: Edições Asa, 1996 ( $1^{\text {a }}$ ed. francesa 1992).

${ }^{33}$ VIEIRA, António - História do Futuro, cap. IV, p. 72-73, cap. V, p. 85, cap. VIII, p. 120-122 e 135-136, Introdução, actualização do texto e notas por BUESCU, Maria Leonor Carvalhão, 2a edição, Lisboa, IN-CM, 1992. 
frequentemente invocado pela literatura restauracionista, da mão direita de Cristo que, no dia da aclamação de D. João IV, quando o arcebispo de Lisboa, D. Rodrigo da Cunha, se dirigia da Sé para a casa da Câmara, milagrosamente se despregara da cruz, sucesso no qual se pretende ver um estreito vínculo entre Ourique e a independência do reino ${ }^{34}$. A Restauração significava a refundação da monarquia, e o retomar de uma legitimidade estabelecida pelo próprio Cristo em Ourique. O despregar miraculoso do braço da cruz era um dos múltiplos sinais que mostravam a legitimidade do novo monarca, herdeiro das promessas de Cristo a Afonso Henriques. Este episódio manteria uma aceitação considerável, no âmbito de uma leitura providencialista da Restauração e, de modo mais lato, da história nacional ${ }^{35}$.

Pode, portanto, afirmar-se que no século XVII a representação histórica e historiográfica das origens, no quadro acima delineado, se ancorava, com uma frequência eloquente, nessa "constelação mítica" em torno de Ourique. Assim, por exemplo, a Genealogia dos Reis de Portugal (1653), no fundo uma síntese da história do reino, incorpora, no que diz respeito às origens do Portugal, todo o aparelho de Ourique, desde a narrativa do milagre, incluindo o "juramento" de Afonso Henriques (fols. 5-13), as Cortes de Lamego (fols. 279-289) e uma cópia do "juramento"do primeiro rei (fols. 291-297v) ${ }^{36}$. O episódio de Ourique é também uma referência nuclear na oratória patriótica pós-aclamatória, estudada de modo sistemático na sua plurifuncionalidade

${ }^{34}$ Como é flagrante na obra $A$ Santidade do Monarca Ecclesiástico Innocencio X. Expoem Portugal as causas de seu sentimento, \& de suas esperanças, obra publicada anónima, em Lisboa, por Paulo Craesbeek, 1646, e atribuída a João Pinto Ribeiro, p. 41-42.

${ }^{35}$ É o caso mais tardio da obra A Politica Moral, e Civil Aula da Nobreza Lusitana, Tomo VI (1754), Livro III, cap. X, 380, da autoria de CASTRO, Damião António de Faria, autor aliás muito citado no âmbito da polémica oitocentista, onde se regista, no capítulo respeitante à "feliz Acclamação de El Rey D. João IV", a ocorrência pública daquele episódio milagroso. Este surge de forma recorrente nos sermões da época, como estudou, de forma exaustiva, MARQUES, João Francisco - A Parenética Portuguesa ..., cit.; IDEM - A Utopia do Quinto Império ..., cit.; e o próprio João Pinto Ribeiro, nas Injustas successoens dos Reys de Leam e de Castella: \& isenção de Portugal, Lisboa: Pedro Craesbeeck, 1642, refere como sinal da aprovação divina que sempre coube a este Reino o episódio do despregar do braço da cruz (ed. Obras Varias..., T. II, Coimbra: José Antunes da Silva, 1730, p. 112). A representação do episódio consta também de um pano de azulejos, de um importante conjunto de cenas alusivas aos momentos mais importantes da Restauração, no jardim do Palácio dos Condes de Almada, hoje Palácio da Independência.

${ }^{36}$ BA, cod. 49-XI-46. 
por João Francisco Marques, e surge também de forma explícita e destacada na argumentação de figuras que tiveram um protagonismo assinalável na diplomacia da Restauração, como é o caso de António de Sousa de Macedo e António Pais Viegas. Os exemplos poderiam multiplicar-se o que, não invalidando o facto de a sua utilização hiperbólica radicar na sua condição de objecto de propaganda numa conjuntura particular, aponta para a presença inequívoca desta "constelação mítica" - origens/Ourique/ /juramento/ povo eleito/ refundação em 1640 - num discurso político-ideológico que servia o Coroa. No limite, poderá estabelecer-se o contraste entre o tradicionalismo e o arcaísmo deste edifício ideológico, articulado e inscrito na dinâmica de resistência à monarquia dual, e o factor de "modernidade" que aquela representou em termos institucionais e do próprio desenvolvimento do Estado ${ }^{37}$.

Emblemático do estreito vínculo estabelecido entre uma restauração "prodigiosa" e a sanção sagrada que presidiu à fundação do reino, e do eco que o próprio poder lhe conferia, acaba por ser o facto de, logo nas primeiras cortes celebradas após a Restauração, em 1641, D. João IV ser instado pela nobreza a retomar o processo de canonização de Afonso Henriques, juntamente com o de Nuno Álvares Pereira ${ }^{38}$ - um, o herói fundador do reino, o outro o "fundador" da Casa de Bragança, agora transformada em Casa Real. Sentido idêntico parece ter a primeira edição da Crónica de D. João I (I Parte), publicada em 1644 e oferecida a D. João IV, que ostentava no rosto a representação do milagre que presidira à fundação do reino.

E chegamos ao século XVIII. No século XVIII encontramos, é certo, a posição crítica de um Luís António Verney, que no Verdadeiro Método de Estudar, publicado em 1746, punha em causa a veracidade da aparição e a pertinência da tradição de Ourique ${ }^{39}$, assim como casos, embora raros, em que é possível entrever as reservas que o episódio suscitava, para lá da

${ }^{37}$ HESPANHA, António - O Governo dos Áustrias e a "modernização" da constituição política portuguesa. Penélope. Fazer e Desfazer a História. 2 (1989) 49-73.

${ }^{38}$ Capitulos Gerais apresentados a ElRey D. Ioão nosso Senhor IIII deste nome, XVIII Rey de Portugal, nas cortes celebradas em Lisboa com os tres Estados em 28 de Ianeiro de 1641, Lisboa: Paulo Craesbeeck, 1645, cap. XXXVI da Nobreza, p. 60.

${ }^{39}$ A propósito das obras de carácter profético e messiânico do P. António Vieira. VERNEY, Luís António - Verdadeiro Método de Estudar, Tomo I, Valença: Off. de Antonio Balle, 1746, p. 206-208. 
sua legitimação oficial. A Verdade das Historias por Questões Problematicas (1701) da autoria de Luís Nunes Tinoco, contador do Tribunal dos Contos do Reino, obra de carácter sincrético que inventaria e discorre sobre mais de cem questões objecto de controvérsia entre vários autores, inclui entre elas a aparição de Cristo a Afonso Henriques ${ }^{40}$. Mas tais posições parecem ser excepcionais, e provenientes "das margens", se assim podemos dizer - como é o caso, de certa maneira, do próprio Verney. Na verdade, a tradição de Ourique mantinha uma apreciável importância ideológica e uma vitalidade talvez supreendente. A Relaçam Verdadeira da Appariçam de Christo Senhor Nosso, no Campo de Ourique, ao Santo Rey Dom Affonso Henriques, e da Batalha, em que Venceo cinco Reis, e Quatrocentos mil Mouros, publicada em 1753, de Dionísio Teixeira de Aguiar, familiar do Santo Ofício, é a este respeito significativa.

A Relaçam Verdadeira... sintetizava, por um lado, os elementos essenciais da já secular tradição de Ourique e, por outro, reflectia os parâmetros da sua aceitação no século XVIII. Das três licenças que autorizavam a sua publicação, duas - a do Santo Ofício e a do Ordinário - incidiam, naturalmente, no facto de a Relaçam não conter "cousa alguma contra a Fé, ou bons costumes". A terceira licença, do Paço, justificava a aprovação no facto de o conteúdo da obra corresponder à celebração de "[...] hum dos pontos mais certos e infalliveis da nossa Historia". Este parecer era da autoria de Filipe José da Gama, membro da Academia Real da História, dos Árcades de Roma e de várias sociedades literárias existentes no país, o que nos parece significativo, bem como, evidentemente, o facto de emitir o parecer na sua qualidade de censor régio.

É ideologicamente relevante constatarmos, como já tivemos ocasião de assinalar em estudos anteriores sobre a construção do episódio fundador, que a elite erudita setecentista, através de alguns dos seus mais prestigiados nomes, concedeu um importante lugar ao milagre de Ourique na constituição da memória nacional. Assinalar tal facto no contexto da inserção ideológica e intelectual do texto que estudamos é importante, pois que, justamente,

${ }^{40}$ BGUC, cod. 345, TINOCO, Luís Nunes - Verdade das historias por questões problematicas. Em que se apontão as razões, que dão os Autores sobre varias opiniões de algûas cousas, que ou se tê por fabulozas, ou não ha de ellas certeza constante, fols. 157-159. 
nos encontramos agora numa época mais ou menos contemporânea em que viveu o autor da Fidelidade Portugueza. A este respeito são de destacar os casos de Barbosa Machado na sua monumental Bibliotheca Lusitana, na entrada relativa a Afonso Henriques, (T.I, 1741) ${ }^{41}$, de António Caetano de Sousa no Agiologio Lusitano $(1744)^{42}$ e, mais significativo ainda, na Historia Genealogica da Caza Real Portugueza, em cujo Tomo I (1735), no capítulo dedicado a Afonso Henriques, se veicula todo o aparelho lendário de Ourique ${ }^{43}$, figurando o texto do "juramento" nas respectivas Provas $(1739)^{44}$, do erudito Frei Manuel do Cenáculo Villas-Boas nos Cuidados Literários $(1791)^{45}$, ou ainda de Tomás Caetano de Bem nas Memorias Historicas e Chronologicas da Sagrada Religião dos Clerigos Regulares... $(1792)^{46}$, entre outros nomes que poderiam aqui ser invocados ${ }^{47}$.

Não espanta, pois, que muitos anos mais tarde o P. Francisco Recreio, o mais violento adversário de Herculano na polémica oitocentista sobre o milagre quando, carreando "testemunhos" em favor da veracidade da

${ }^{41}$ Bibliotheca Lusitana, Tomo I, 1741, p. 11-15.

${ }^{42} \mathrm{O}$ Tomo IV do monumental Agiologio Lusitano dos Santos, e Varões Illustres em virtude do Reino de Portugal, e suas Conquistas, Lisboa, Regia Officina Sylviana, e da Academia Real, 1744, continuação da obra iniciada por Jorge Cardoso em 1652 consagra, na efeméride respeitante ao dia 25 de Julho, uma pormenorizadíssima referência ao episódio de Ourique (280-285), e o respectivo "Commentario" (289-301), que inclui o texto do juramento em latim e português, é uma sequência cerrada de autores nacionais e estrangeiros que referem o milagre de Ourique. Este conjunto de autoridades veiculado por António Caetano de Sousa seria, aliás, um dos argumentos mais invocados pelos defensores de Ourique na polémica que teria lugar com Herculano no século XIX.

${ }^{43}$ História Genealógica da Casa Real Portuguesa, $2^{\mathrm{a}}$ ed. Tomo I, Coimbra: Atlântida Editora, 1946, p. 32-36.

${ }^{44}$ Provas da História Genealógica da Casa Real Portuguesa, Tomo I, Coimbra: Atlântida Editora, 1946, p. 7-9.

${ }^{45}$ Cuidados Literarios do Prelado de Beja em graça do seu Bispado, artigo intitulado "Historia Ecclesiastica", Lisboa: Off. de Simão Thaddeo Ferreira, 1791, p. 361-401. Atribuída à sua autoria existe ainda uma obra constituída por uma pequena introdução de exaltação de Ourique e por sete estampas, intitulada Graças concedidas por Christo no Campo de Ourique, acontecidas em outros tempos e repetidas no actual, conformes aos desenhos de suas idades, Lisboa: Impressão Régia, 1813.

${ }^{46}$ BEM, Tomás Caetano de-Memorias Historicas e Chronologicas da Sagrada Religião dos Clerigos Regulares em Portugal e suas Conquistas, na India Oriental, T. I, Lisboa: Régia Off. Typ., 1792, p. 167.

${ }^{47}$ Sobre o tratamento do milagre de Ourique pela Academia Portuguesa de História, v. MOTA, Isabel Ferreira da - A Academia Real da História. Os intelectuais, o poder cultural e o poder monárquico no séc. XVIII. Coimbra: Minerva, 2003, p. 72-73. 
aparição, invocava com particular ênfase o século XVIII que, com uma acentuada "tendencia para desmoronar o edificio das velhas crenças historicas", não abatera, contudo, a tradição de Ourique ${ }^{48}$. E não era essa a indiscutida imagem das origens, a ser pedagogicamente incutida e transmitida aos nobres e filhos da aristocracia, como veiculava A Politica Moral, e Civil Aula da Nobreza Lusitana, publicada em 1754, da autoria de Damião António de Faria e Castro? ${ }^{49}$

Este empenhamento da erudição setecentista em sustentar o "monumento" de Ourique deve ser visto em articulação com a importância que a Coroa e a Igreja continuam a conferir ao processo de canonização de Afonso Henriques, processo em que, no reinado de D. João V, e ainda no de D. José, D. João de Santa Maria de Jesus, cónego regular de Santa Cruz de Coimbra, assumiu notoriedade na sistematização de materiais tendentes a fundamentar um pedido ${ }^{50}$ a que era dado um cunho público e nacional ${ }^{51}$

${ }^{48}$ RECREIO, P. Francisco - A Batalha de Ourique e a Historia de Portugal de A. Herculano. Contraposição Critico-Historica, Parte I, Lisboa: Typ. de G. M. Martins, 1854, p. 39.

${ }^{49}$ CASTRO, Damião António de Faria e - A Politica Moral, e Civil Aula da Nobreza Lusitana, Tomo VI (1754), Livro III, cap. X, p. 380.

${ }^{50}$ Materiais que constam, nomeadamente, das suas obras Fama Posthuma do Gloriosissimo Senhor Rey D. Affonso Henriques, primeiro Monarcha do Imperio Lusitano, com a noticia do estado da sua Canonização, e dos Quesitos sobre as acções do Senhor Rey D. Affonso Henriques em ordem à sua canonização (1752). V. BROCHADO, I. F. da Costa - Tentativas de canonização de El-Rei D. Afonso Henriques. Anais da Academia Portuguesa da História, $3^{\mathrm{a}}$ série, VIII (1958) 307-337.

${ }^{51}$ Em edital público, não datado, publicado provavelmente em 1747, por ocasião da instrução do processo no reinado de D. João V, encimado por uma água-forte representando a aparição de Cristo a Afonso Henriques, pedia-se que "[...] toda a pessoa, q tiver noticia de algumas Imagens do Virtuoso Rey D. Affonso, ou de culto, respeito, veneração pública, ou particular, que se lhe tribute: ou tiver, ou souber de alguns livros não impressos, ou qualquer genero de documentos, e papeis manuscriptos, e ainda livros, e papeis impressos, se forem raros, q fallem do Veneravel Rey, queira por serviço de Deos, e de Sua Magestade, por honra da Nação, e pela muita obrigação, q todos os Portuguezes devem ter a este nosso primeiro Libertador, dar parte do q tiver, ou souber: o que cada hum poderá fazer cõmunicando-o por si, por via dos seus Parochos, ou por quem lhe parecer, aos Senhores Ordinarios das suas Dioceses, ou aos Prelados das Casas Professas, e Collegios da Companhia de Jesus, ou de Mosteiros de Conegos Regulares de Santo Agostinho; os quaes todos tem aviso, para remetterem as noticias, $q$ se lhes derem, em ordem a se mandarem para Roma". O exemplar consultado faz parte do cod. 1520 da BGUC, maço contendo três items: uma cópia dos cento e quarenta quesitos sobre os quais deveria assentar o processo de canonização, com o título Conimbricensis Canonizationis Servi Dei Alphonsi Henrici, seu Henrichij primi Portugallie Regis Sancti Nuncupati, dos quais há vários outros manuscritos noutras bibliotecas (BNP, cod. 572, 573, 742, 883; BA, 49-II-15, e várias no IAN/TT). 
num contexto em que o messianismo político joanino deve ser sublinhado ${ }^{52}$. Ainda no século XVIII o patriarca D. Tomás de Almeida solicitava ao Papa Bento XIV a concessão ao clero português, em virtude da grande devoção em Portugal pelas Cinco Chagas de Cristo, do ofício e missa das Cinco Chagas, existente desde 1733. Requeria-se ainda a concessão de um aditamento ao ofício, na versão especialmente destinada a Portugal, de um texto referente ao aparecimento de Cristo a Afonso Henriques, numa explícita referência à relação que se considerava existir entre o milagre e a inscrição das cinco chagas no brasão nacional. Tanto o ofício como o aditamento referente à aparição foram concedidos por Roma em $1753^{53}$. No século XIX, este aditamento seria invocado por alguns defensores da aparição como testemunho coevo do milagre, da autoria de S. Bernardo de Claraval, e nessa medida considerado como uma das provas mais importantes do milagre, equívoco que Alexandre Herculano se apressaria a desmontar em 1850, no célebre opúsculo Eu e o Clero ${ }^{54}$.

Já nos finais do século, o P. António Pereira de Figueiredo, da Congregação do Oratório, grande teórico do regalismo pombalino, publicava os Novos Testemunhos da milagrosa apparição de Christo Senhor Nosso a El Rei D. Affonso Henriques antes da famosa Batalha do Campo d'Ourique, e Exemplos paralellos, que nos induzão à pia crença de tão portentoso caso $(1786)^{55}$. Discurso porventura já defensivo na sua estrutura e na sua

O segundo item é uma obra manuscrita, em cuja capa se lê ter pertencido à Livraria do Mosteiro de Santa Cruz de Coimbra, intitulado Officiû Propriû B. Alphonsi Primi Lusitaniae Regis, 17 fols. não numerados. O terceiro é constituído pelo edital que referimos.

${ }^{52}$ ARAÚJO, Ana Cristina - Morte Memória e Piedade Barroca, Revista de História das Ideias, 11 (1989) 154 e ss.

${ }^{53}$ Pode ver-se o texto do decreto que fez a concessão do ofício para Portugal em 1753 em PAIVA, Dionízio António de - Quintanário Meditativo, e Fervorosa supplica em louvor das sinco Chagas de Nosso Senhor Jesus Christo. Offerecido ao mesmo Senhor, e por Elle dadas, para Brazoens do seu imperio, ao Real Tronco Luzitano, Lisboa: Off. de José de Aquino Bulhoens, 1797.

${ }^{54}$ BUESCU, Ana Isabel - O Milagre de Ourique..., cit., p. 38-39.

${ }^{55}$ Este texto do P. António Pereira de Figueiredo é reeditado em 1809 com aditamentos, na Impressão Régia, numa conjuntura bem específica e sob o título sugestivo de Dissertação historica e critica, em que se prova a milagrosa apparição de Christo Senhor Nosso a El Rei D. Affonso Henriques antes da famosa Batalha do Campo de Ourique, publicada em 1786 por seu author o erudito P. Antonio Pereira de Figueiredo, Agora novamente accrescentada com o auto do juramento do mesmo rei em Latim e Portuguez, e com varias anotações e authoridades, que devem persuadir, e convencer a todos os fieis portugueses da verdade de 
articulação, os Novos Testemunhos..., da autoria de um homem de grande prestígio intelectual, seriam objecto de ampla divulgação, e a sua importância na fundamentação da veracidade da aparição culminaria, aliás, no lugar de relevo que assumiriam na polémica oitocentista sobre o milagre ${ }^{56}$.

\section{A Fidelidade Portugueza e o seu programa iconográfico}

Regressando à Fidelidade Portugueza, poderemos agora perceber melhor como as ideias centrais em que assenta a sua construção e o seu discurso não são, ao contrário do que poderia fazer crer uma leitura mais apressada ou, sobretudo, cultural e ideologicamente descontextualizada, um mero efeito ou artifício retórico ao serviço da monarquia - e do seu autor - mas antes uma síntese que reactualizava, projectando-a de novo, uma certa ideia, uma certa imagem, uma certa representação da monarquia portuguesa, que fora, afinal, lentamente edificada ao longo dos séculos. E esta imagem, em que a "constelação mítica" de Ourique tem um lugar de privilégio, interage com um outro elemento que assume uma dimensão singular na Fidelidade Portugueza: a iconografia.

\subsection{Reis e rainhas de Portugal}

$\mathrm{Na}$ verdade, o "investimento iconográfico" desta obra tem, no seu conjunto, uma inegável relevância e interesse: nela podemos encontrar, à medida que se desenrolam as "Breves Reflexões" sobre cada um dos reis de Portugal, pequenas sínteses de vida e acções de cada monarca, incluindo o conde D. Henrique, "Gloriozo Progenitor da Monarquia Luzitana"57. Maior destaque visual tem ainda uma galeria completa de "retratos", ou melhor, de representações das efígies de todas as rainhas de Portugal

hum facto tão portentozo. Offerecida à Nação Portugueza por hum dos seus mais verdadeiros Patriotas, para os animar e esforçar nas presentes circunstancias da guerra contra os inimigos da Religião e do Throno.

${ }^{56}$ V. BUESCU, Ana Isabel - O Milagre de Ourique...., cit., p. 83-90.

${ }^{57}$ Fidelidade Portugueza..., fols. 10-22. 
até D. Maria I - com a excepção de D. Mécia, mulher de D. Sancho II (1209?10-1248), o medieval "rex inutilis", que veio a ser deposto. Também a "Breve Reflexão" relativa ao igualmente deposto D. Afonso VI ${ }^{58}$ não é acompanhada da efígie da rainha D. Maria Francisca, que "transita" para o texto relativo a D. Pedro II, antecedendo o retrato de D. Maria Sofia, segunda mulher deste monarca ${ }^{59}$. Imaginadas umas, como as efígies das rainhas medievais, visivelmente inspiradas em retratos fixados pela pintura ou pela gravura para os casos mais recentes, não tendo embora qualidade artística, estas efígies constituem, sem dúvida, um dos pontos de interesse iconográfico deste manuscrito (Figura 1).

Figura 1

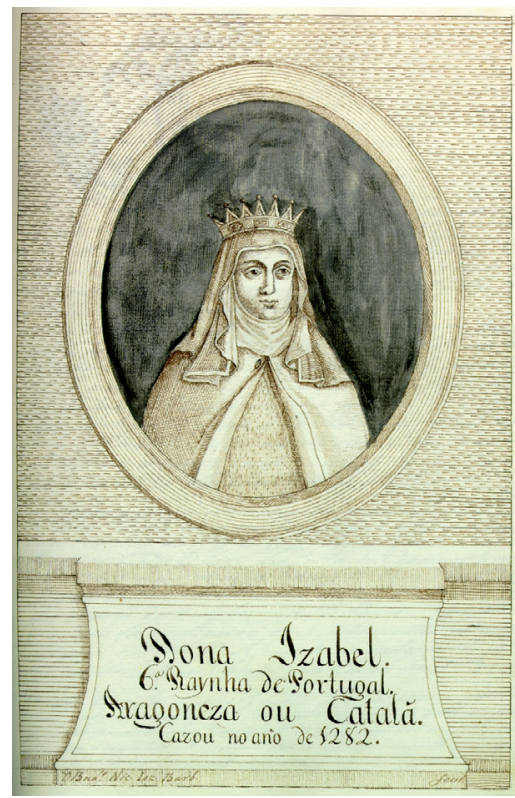

Curiosamente, não existem as efígies dos reis, facto que nos parece, em parte, apenas explicável por ser um momento em que o poder político se declinava no feminino, já que era uma mulher, D. Maria I, que então ocupava o trono. Em todo o caso, é flagrante o contraste entre um texto que é

\footnotetext{
${ }^{58}$ Ibidem, fols. 148-151.

${ }^{59}$ Ibidem, fols. 152-160.
} 
organizado em torno da memória dos monarcas reinantes, mas sem lhes seja associada uma imagem, ao contrário do que acontece com as rainhas, em que o poder evocativo da imagem se substitui ao próprio texto. Não deixa de ser significativo verificar como, nesta seriação, enquanto o conde D. Henrique surge na sua condição de "Gloriozo Progenitor da Monarquia Luzitana", D. Teresa, sua mulher, é expressamente apresentada como primeira rainha de Portugal; desta forma, D. Mafalda, mulher do rei Fundador acaba por surgir como segunda rainha de Portugal...

$\mathrm{A}$ única excepção a esta galeria no feminino é a do rei D. João $\mathrm{V}$, representado numa magnífica e majestosa imagem, que contudo não identificámos no âmbito da abundante iconografia deste monarca (Figura 2) ${ }^{60}$.

Figura 2

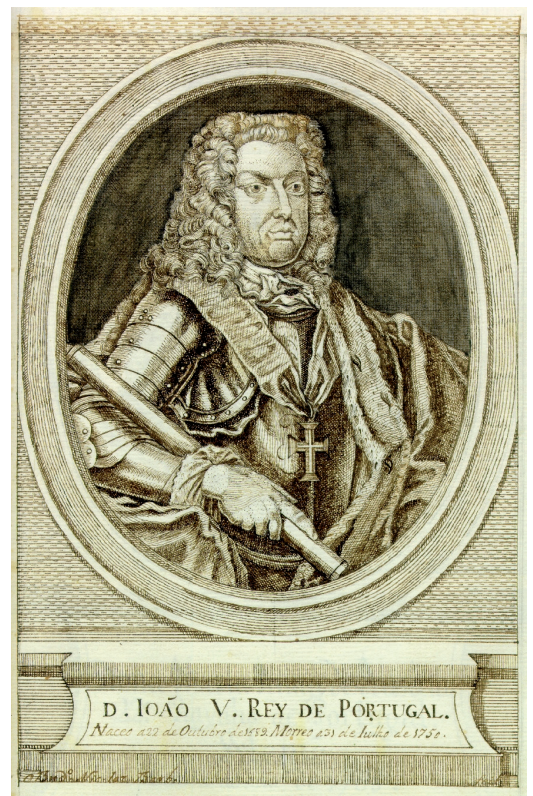

Como figuras masculinas de condição régia temos ainda a meia e encoberta efígie de D. Pedro III, casado com D. Maria I e, finalmente o herdeiro da coroa, filho primogénito de D. Maria I, D. José Francisco, príncipe

${ }^{60}$ Sobre os retratos e iconografia régia deste monarca, v. SALDANHA, Nuno (coord.) - Joanni V Magnifico. Lisboa: IPPAR, 1994. 
do Brasil, numa gravura que também pensamos ser desconhecida, não figurando em qualquer elenco das imagens que se conhecem deste príncipe ${ }^{61}$ (Figura 3). Pelo aparato, composição e majestade, era bem o retrato do futuro rei de Portugal, envergando armadura, ostentando a cruz de Cristo

Figura 3

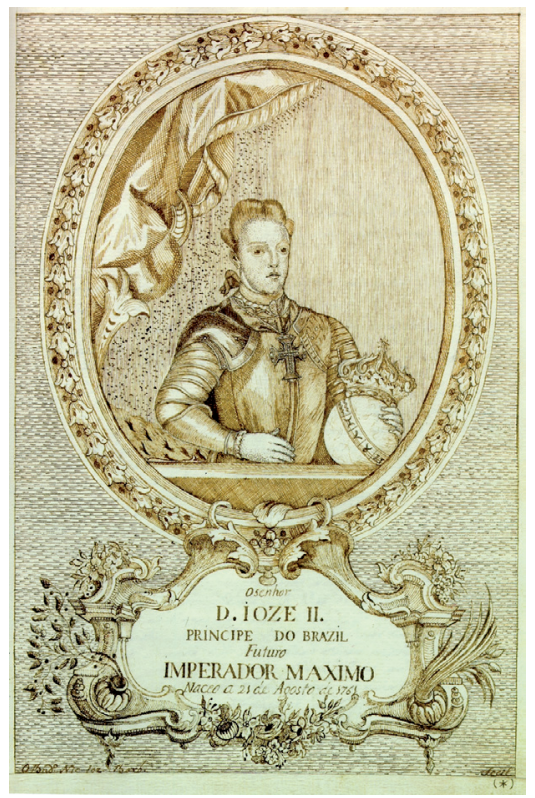

ao peito e segurando um globo com os signos do zodíaco encimado por uma coroa. Para o autor da Fidelidade Portugueza, tratava-se do "futuro Imperador Maximo", como pode ler-se na respectiva legenda. Surge ainda a evocação imagética de um outro rei, embora recorrendo-se a uma estratégia iconográfica diferente: em vez de um retrato ou efígie do rei, assinala-se a memória de $\mathrm{D}$. José através de um desenho à pena que reproduz de forma fiel o monumento equestre do monarca, da autoria de Machado de Castro, inaugurado em $1775^{62}$.

${ }^{61} \mathrm{~V}$. o exaustivo levantamento iconográfico em No $2{ }^{\circ}$ Centenário da Morte do Príncipe D. José (1761-1788), cit.

${ }^{62}$ Fidelidade Portugueza..., fol. 182. 


\subsection{A emblemática régia}

Além da galeria de efígies das rainhas e dos retratos de D. João V e do príncipe D. José, a Fidelidade Portugueza inclui uma notável sequência relativa à emblemática régia, com os desenhos, aguarelados, dos escudos de armas e das empresas de quase todos os reis de Portugal até D. Maria I ${ }^{63}$. Nesta referenciação e identificação da memória dos reis passados não falta a indicação do respectivo cognome, pormenor que acaba por se revelar interessante, pois podemos ver como vários coincidem com os actuais cognomes, mas não todos. São eles: Afonso Henriques, o Conquistador; Sancho I, o Povoador; Afonso II, o Legislador; Sancho II, o Magnifico; Afonso III, o Restaurador; Dinis, o Justo; Afonso IV, o Ousado; Pedro I, o Rigoroso; Fernando, o Gentil; João I, o Vingador; Duarte, o Eloquente; Afonso V, o Guerreiro; João II, o Perfeito; Manuel, o Feliz; João III, o Piedoso; Sebastião, o Animoso; Henrique, o Casto; João IV, o Afortunado; Afonso VI, o Afável; Pedro II, o Pacífico; João V, o Espiritual; José I, o Triunfante. Sintetizando a memória dos reis e do reino, não falta também uma imagem com a "Chronologia dos Senhores Reys de Portugal", uma grande esfera com o mapa de Portugal e as armas régias no centro e, 11 em círculos concêntricos referindo, de dentro para fora: número de ordem do rei desde o início da monarquia portuguesa; o nome do monarca; data de nascimento; local de nascimento; idade de ascensão ao trono; nome da rainha consorte; anos de reinado; idade que tinha quando morreu; ano da morte; lugar da morte; lugar de sepultura (Figura 4).

Relevante é, ainda, e também em articulação com uma breve mas interessante descrição do reino de Portugal e suas províncias, a presença de um elemento poderosamente identificador - os emblemas das cidades de cada província, desenhados com minúcia e aguarelados ${ }^{64}$.

${ }^{63}$ Muito provavelmente, várias delas são historicamente infundadas, ou pelo menos reconstituídas, embora não todas - como é o caso da empresa de D. João II, visualmente muito conseguida. Fidelidade Portugueza..., cit., fol. 108.

${ }^{64}$ Ibidem, fols. $131 \mathrm{v}-143$. 
Figura 4

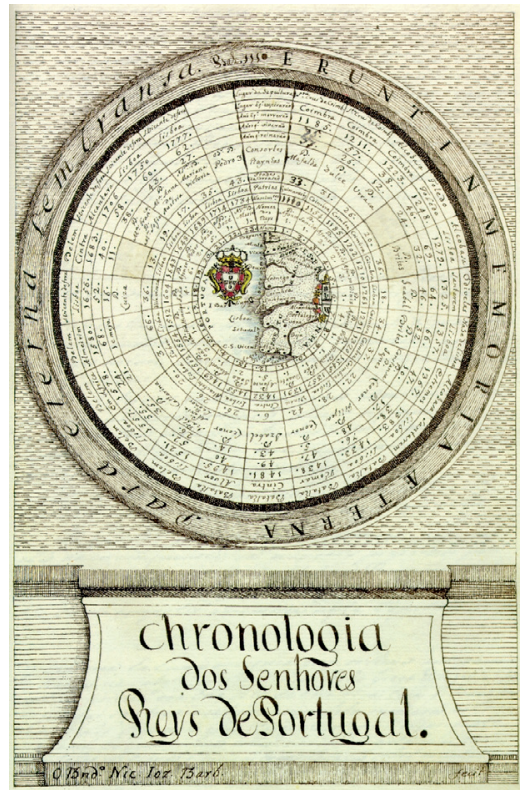

\subsection{Um destino universal}

Mas, como dizíamos, é na ideia central deste texto, proclamando um destino universal para o sucessor da coroa portuguesa, em que a utopia política se cruza com a ideia de um Portugal profetizado, que o programa iconográfico da Fidelidade Portugueza encontra, do nosso ponto de vista, a sua mais expressiva materialização. Desde logo, no desenho aguarelado, personificando, numa imponente figura feminina, a Fidelidade Portuguesa e 0 seu destino imperial. Esta figura, cujos olhos se voltam para os céus, de onde emana a palavra divina de incitamento presente no texto do Juramento do primeiro monarca - Deferatur nomen meum in exteras gentes - sustenta com a mão direita um pendão com o nome de Cristo, na mão esquerda segura uma chave de grandes dimensões, e ostenta ao pescoço um colar de onde pende o escudo português. Encontra-se em pé, sobre o orbe terrestre, com todos os continentes representados, assinalando a Europa com o pendão. O cenário é o oceano e as naus partindo, identificadas com bandeiras portuguesas. O destino imperial atribuído a Portugal é bem patente no amontoado de 
coroas reais que jazem no canto inferior direito da imagem, caídas de uma coluna/pedestal em que, sobre uma almofada de veludo escarlate, se encontra uma única coroa, sobrepujada pela cruz de Cristo, e um ceptro, destinados ao futuro D. José II: primeira imagem no início de uma obra que, doravante, se coloca simbolicamente sob o signo da alegoria (Figura 5).

Figura 5

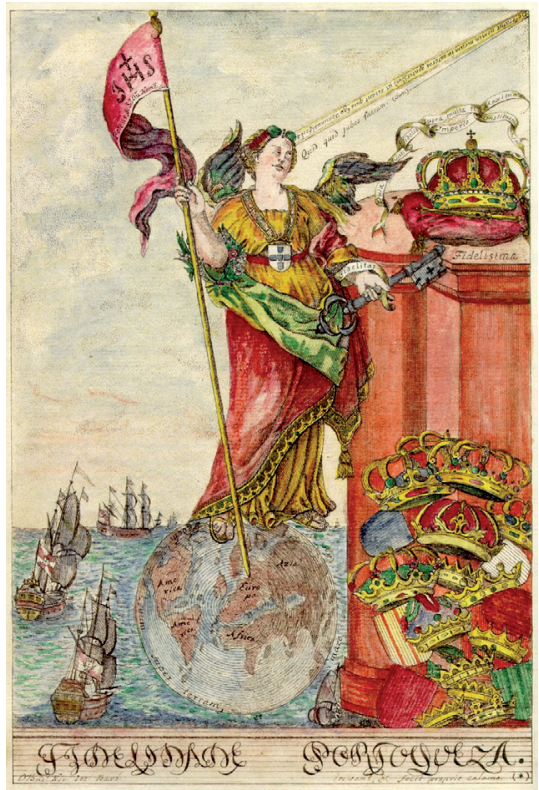

Se é esse o destino português, a desempenhar e a cumprir pelo príncipe do Brasil, entende-se que o relato fundacional do reino, onde foi feita a primeira solenização de um destino a cumprir, ocupe um lugar de relevo nas páginas dedicadas a Afonso Henriques, “[...] o Conquistador, Tronco da Geração Real $1^{\circ}$ Hercules Luzitano" "65. Na verdade, todas as "peças" que desde o século XV foram escorando o episódio fundador lá estão, com o devido e natural destaque na Fidelidade Portugueza: a narrativa do milagre, tal como a cronística a veio a fixar e foi amplamente difundida, o "Juramento" de Afonso Henriques, em latim e em português ${ }^{66}$; o texto das Cortes de

\footnotetext{
${ }^{65}$ Ibidem, fols. 23-43.

${ }^{66}$ Ibidem, fols. 27-30
} 
Lamego, também em latim e português ${ }^{67}$ e até a voz de Luís de Camões n' Os Lusíadas (1572), cujos versos sobre a aparição se transcrevem ${ }^{68}$. No interior do texto, assumindo uma centralidade que é também simbólica, encontramos a necessária, e diríamos quase "inevitável" tradução iconológica, com um desenho aguarelado da "Prodigiosa aparisão [sic] de Jesus Cristo no Campo de Ourique", incorporando todos os elementos "canónicos" do episódio fundador ${ }^{69}$ (Figura 6).

\section{Figura 6}

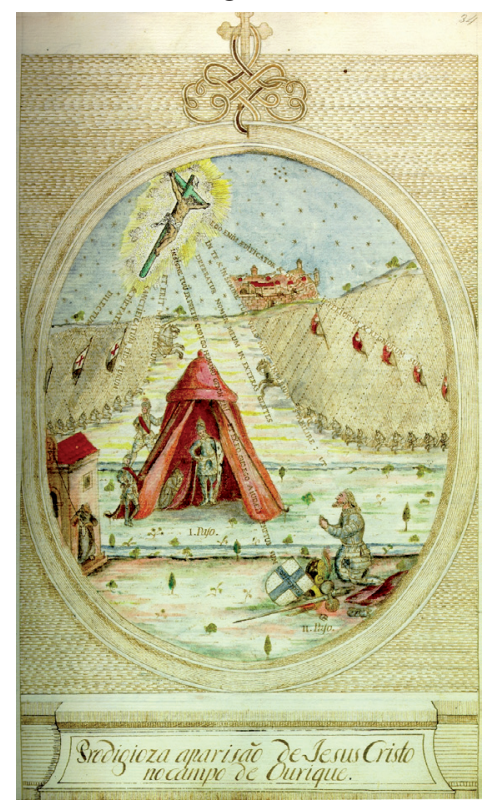

Aliás, como já sugerimos, depois da nova e decisiva funcionalidade do episódio fundador na Restauração, o "racional" século XVIII, com a chancela da mais destacada erudição setecentista, tem um papel mais importante do que normalmente se lhe atribui na legitimidade e no triunfo da constelação mítico-política de Ourique - da "aparição" promissória de Cristo às Cortes de Lamego, passando pela sacralização da figura do primeiro monarca

\footnotetext{
${ }^{67}$ Ibidem, fols. $35 \mathrm{v}-39 \mathrm{v}$.

${ }^{68}$ Ibidem, fol. 33.

${ }^{69}$ Ibidem, fol. 34 .
} 
- na memória da realeza portuguesa. Digamos que, com D. João V, essa constelação se torna, também, um "emblema" da grandeza e da majestade de um rei e de uma monarquia - não por acaso, como vimos, é no reinado de D. João $\mathrm{V}$ que se verifica um novo e oficial impulso ao processo de canonização de Afonso Henriques ${ }^{70}$. E esse triunfo é indissociável de uma dimensão iconográfica, como testemunha a cada vez mais comum inserção do episódio nas árvores genealógicas dos Reis de Portugal, sejam elas mais imponentes, como é o caso da árvore que podemos ver na Academia das Ciências, em Lisboa ${ }^{71}$ ou mais modestas, como sucede em tantas obras de carácter genealógico que existem em profusão nas nossas bibliotecas ${ }^{72} \ldots$

Mas outras imagens ainda enfatizam, algumas delas de forma visualmente bastante elaborada, esse papel singular confiado por Cristo à monarquia portuguesa, como podemos ver na árvore dos reis portugueses desde a fundação, em que, nas frases que a acompanham, Ourique surge como óbvia e expressa intertextualidade (figura 7).

\subsection{Um rei que não houve: D. José II}

É portanto sob o signo de uma monarquia profetizada e herdando toda uma história cuja súmula e protagonistas se resumem na já referida "Chronologia dos Senhores Reys de Portugal", "para eterna lembrança" que surge, como que em apoteose, a figura de "Dom José $2^{\circ}$ Principe do Brazil, Futuro Imperador Maximo"73, que havia de ostentar, pois, de acordo com a vontade divina, o imperial diadema inscrito no seu próprio nome (figura 8), reinando sobre toda a terra (Figura 9).

${ }^{70}$ V. supra, notas 50 e 51, e ainda BA, 49-XI-51, Vida do Beamventurado Servo de Deus ElRey D. Afonso Henriques $1^{\circ}$ de Portugal, que tem transcrito no final o texto das Cortes de Lamego.

${ }^{71}$ Árvore Genealógica dos Reis de Portugal. Autor anónimo, meados do século XVIII (a.1760), óleo sobre tela, Academia das Ciências de Lisboa. Reproduzido, por exemplo, em D. João VI e o seu Tempo, Exposição e Catálogo, Palácio Nacional da Ajuda, Maio-Junho de 1999, Lisboa, CNCDP, 1999, p. 169.

${ }^{72}$ V., apenas a título de exemplo, BA, 50-IV-21, fols. 247 e 249, que, pela sua dimensão, e apesar do nosso pedido, não foi tecnicamente possível reproduzir.

${ }^{73}$ Fidelidade Portugueza ..., fols. 198-218. 
De acordo com esta concepção, seria, pois, D. José II a encarnar a fidelidade portuguesa a Cristo e a uma Igreja de destino universal - como pode ver-se nas imagens de teor católico mais explícito, o Mundo Catholico Imperio de Portugal, tendo a seus pés a heresia (Figura 10) e o Triunfo da Santa Fe (Figura 11) -, protagonizando e conduzindo, enfim, o reino de Portugal a cumprir um destino anunciado e prometido ao Rei Fundador. A prematura morte do príncipe do Brasil, em 1788, veio retirar sentido ao edifício "profético" da Fidelidade Portugueza de Nicolau José Barbosa. Mas nem por isso esta deixa de ser um eloquente testemunho de como, ainda em meados do século XVIII, o discurso e a retórica política em torno da monarquia - neste caso com uma importante componente imagética recorria e incorporava uma enraizada representação das origens e do destino do reino de Portugal, entre o sagrado, o profetismo imperial e o profano, no declinar do século das Luzes.

Figura 7

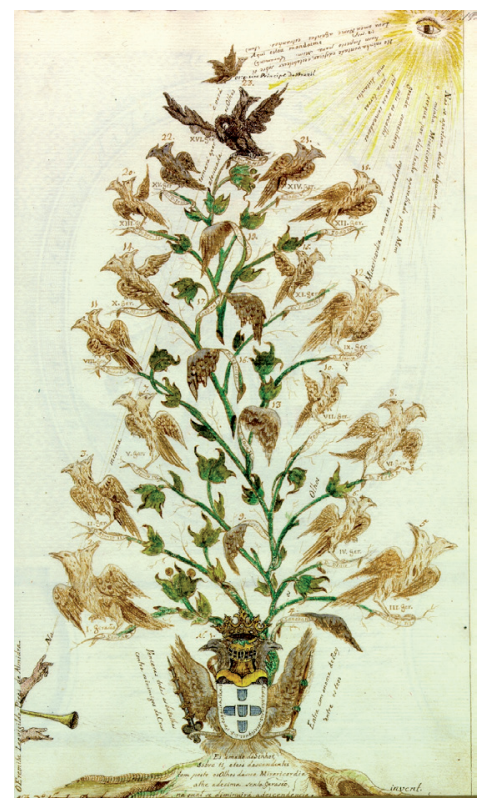

Figura 8

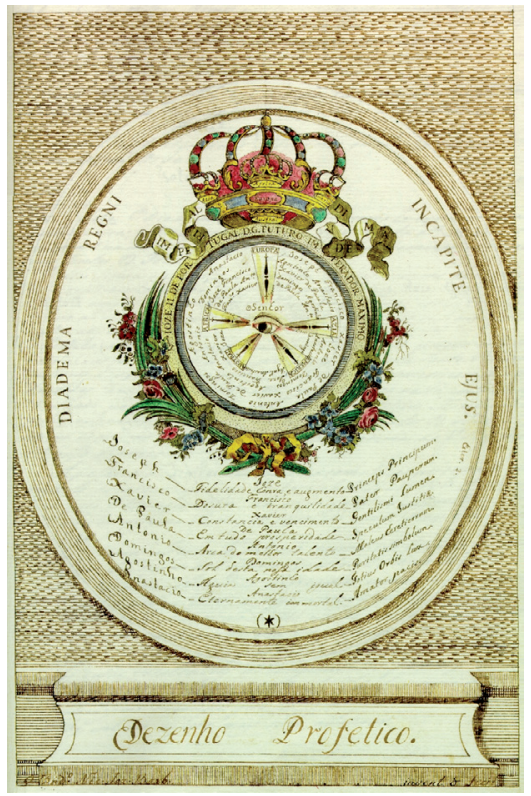


Figura 9

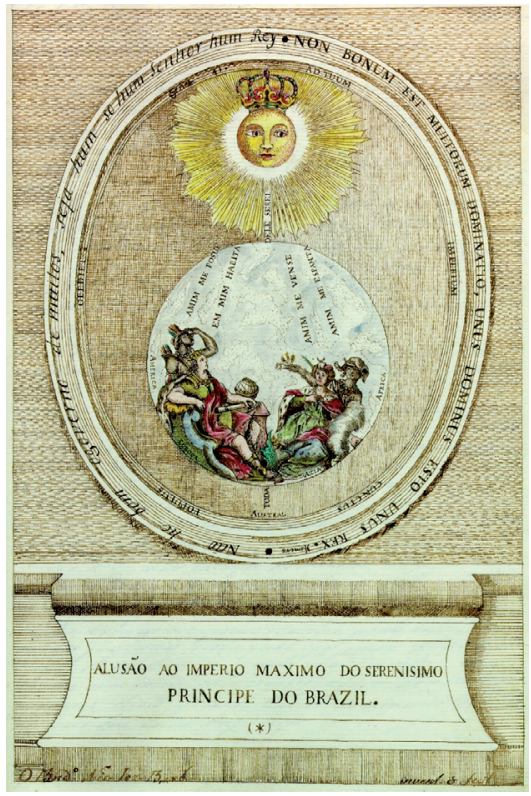

Figura 10

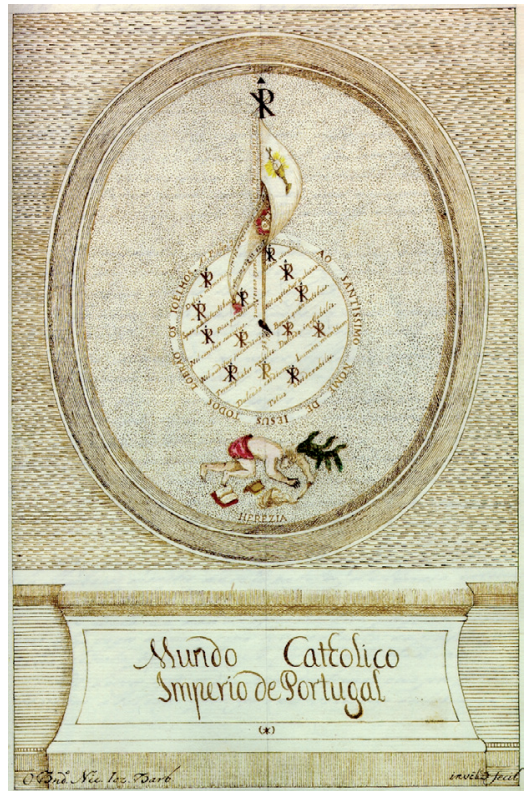

Figura 11

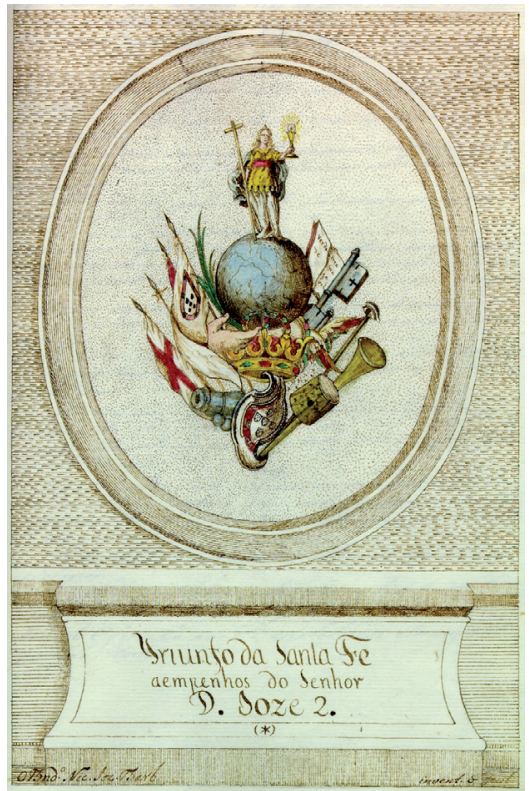

